\title{
WANITA PERAJIN TENUN TRADISIONAL DI NAGARI HALABAN, KECAMATAN LAREH SAGO HALABAN KABUPATEN LIMA PULUH KOTA, SUMATERA BARAT
}

\author{
Hendrawati ${ }^{1}$, Ermayanti ${ }^{2}$
}

\section{Abstract}

Article based on field research in Halaban Village, Lareh Sago Halaban Subdistrict, Lima Puluh Kota District. This village is one of center of weaving traditional craft in West Sumatra, beside that Pandai Sikek and Silungkang, which is the most women activity in this village. The aim of research is described of daily life, work as handicrafts workers woven traditional . The research found that women in this village has two role, besides the housewives, they also breadwinner second after her husband, economically a woman has a high position and an important role in household. This activity very need to overcome in the economy household.

Keywords: Minangkabau, Women Role, Household Economy, West Sumatra

\begin{abstract}
Abstrak
Artikel ini berdasarkan hasil penelitian yang dilaksanakan di Nagari Halaban, Kecamatan Lareh Sago Halaban. Nagari ini merupakan salah satu sentra kerajinan tenun tradisional di Sumatera Barat selain Pandai Sikek dan Silungkang yang digeluti oleh wanita di nagari tersebut. Tujuan penelitian adalah mendeskripsikan keseharian wanita di nagari Nagari Halaban, Kecamatan Lareh Sago Halaban Kabupaten Lima Puluh Kota yang bekerja sebagai perajin tenun tradisional. Dari hasil penelitian pada wanita perajin tenun tradisional dapat di ketahui bahwa para perempuan di nagari tersebut mempunyai peranan ganda dalam kehidupan sehari-hari, selain ibu rumah tangga ia juga sebagai pencari nafkah kedua setelah suaminya, secara ekonomis seorang perempuan mempunyai kedudukan dan peranan penting dalam rumah tangganya. Ikut sertanya perempuan sangat di butuhkan untuk mengatasi kesukaran hidup dan kemelaratan yang menimpa keluarganya
\end{abstract}

Kata Kunci: Minangkabau, Peran wanita, Ekonomi Rumah Tangga, Sumatera Barat

A. Pendahuluan

$D$ eran wanita di sektor Usaha Kecil dan Menengah umumnya terkait dengan bidang perdagangan dan industri pengolahan seperti: warung makan, toko kecil, pengolahan makanan dan industri kerajinan, karena usaha ini dapat dilakukan di rumah sehingga tidak melupakan peran wanita sebagai ibu rumah tangga. Meskipun awalnya Usaha
Kecil dan Menengah yang dilakukan wanita lebih banyak sebagai pekerjaan sampingan untuk membantu suami dan untuk menambah pendapatan rumah tangga, tetapi dapat menjadi sumber pendapatan rumah tangga utama apabila dikelola secara sungguh-sungguh. (Priminingtyas, 2010)

Hasil penelitian yang dilakukan Agus Mansur dkk (2008) di Kabupaten

\footnotetext{
${ }^{1}$ Penulis adalah dosen tetap Jurusan Antropologi FISIP Universitas Andalas

${ }^{2}$ Penulis adalah dosen tetap Jurusan Antropologi FISIP Universitas Andalas
} 
Sleman bahwa kunci sukses wanita dalam Usaha Kecil dan Menengah menunjukkan bahwa faktor-faktor perencanaan yang meliputi layanan informasi, konsultasi, bimbingan dan ketersediaan lapangan kerja bagi perempuan serta faktor pelaksanaan pelaksanaan yang meliputi layanan pelatihan, fasilitas pengembangan organisasi dan manajemen, dan juga faktor pengembangan yang terdiri penyeleng garaan kontak bisnis, fasilitas dalam memperluas pasar dan penguasaan teknologi dan yang terakhir faktor motivasi yang meliputi kebutuhan fisiologis, aktualisasi diri dan berprestasi ternyata memiliki hubungan yang simultan dan signifikan. Faktor-faktor tersebut berpenga ruh sebesar $71.6 \%$ terhadap kinerja, sedangkan $28.4 \%$ dipengaruhi oleh faktor lain.

Propinsi Sumatera Barat telah memiliki beberapa dokumen dan profil industri menurut cabang industri yang ada. Menurut database pendataan industri kecil dan menengah tahun 2009 terdapat di dalamnya beberapa cabang industri yang merupakan subsektor dalam klasifikasi sektor industri kreatif. Industri tersebut telah digolongkan menurut KBLI (Klasifi kasi Baku Lapangan Industri) oleh Dinas Koperasi, Perindustrian dan Perdagangan Propinsi Sumatera Barat: industri bordir/ sulaman (kode KBLI: 17293) dan pertenunan (kode KBLI:17114). Kedua cabang industri tersebut termasuk dalam kelompok sektor industri kreatif yaitu 'kerajinan'. Mengingat saat ini dunia in dustri telah berada pada era ekonomi gelombang keempat untuk itu sangat diperlukan perumusan strategi pengemba ngan yang tepat agar industri kreatif dapat berkembang dan Sumatera Barat dapat menciptakan daerah sentra industri kreatif potensial yang dapat bergeliat dalam era ekonomi kreatif gelombang keempat pada masa sekarang ini (Pusparini, 2011).

Bordir/sulaman dan pertenunan merupakan bagian dari seni budaya yang dilahirkan secara turun-temurun dalam ma syarakat daerah Sumatera Barat, khususnya daerah Kabupaten Agam, Ka bupaten Lima Puluh Kota dan Kota Bukittinggi. Usaha kerajinan sulaman ini merupakan sumber mata pencaharian utama bagi masyarakat, di mana lebih kurang $42 \%$ dari jumlah penduduk. Pada beberapa daerah ini bergerak di bidang usaha industri sulaman. Hasil produk industri kerajinan bordir/sulaman dan pertenunan tidak hanya di pasarkan di daerah lokal semata, seperti kota Bukittinggi, Padang dan kota-kota lainnya di Sumatera Barat, tetapi juga sudah tersebar pada pasar nasional maupun pasar ASEAN (Malaysia, Singapura, Brunai) (Yasnidawati, 2011).

Kondisi dan kenyataan yang demikian menunjukkan bahwa pengemba ngan industri kecil ini, terutama industri sulaman di daerah ini memiliki prospek yang baik pada masa mendatang, terutama untuk mendukung pengemba ngan ekonomi kerakyatan. Usaha ini tidak hanya mampu untuk meningkatkan pen dapatan rumah tangga pengrajin tetapi juga dapat menyerap tenaga kerja terutama untuk para wanita. Pengemba ngan industri bordir/sulaman dan perte nunan telah menjadi prioritas utama dalam melestarikan kerajinan rumah tangga, terutama bagi para wanita di Provinsi Sumatera Barat. Sasaran pembangunan industri sulaman adalah untuk mengem bangkan industri kreatif, me mengem bangkan industri kreatif, mening katkan nilai tambah, penyerapan tenaga kerja, sehingga diharapkan dapat meningkatkan pendapatan masyarakat. Hal ini sejalan dengan pendapat Setiawati (2001): "pengembangan pembangunan industri kecil/rumah tangga di berbagai daerah, lebih diarahkan pada terciptanya peningkatan kualitas produk dan nilai tambah hasil produksi serta penyerapan tenaga kerja, sehingga diharapkan dapat meningkatkan pendapatan masyarakat" (Yasnidawati, 2011).

Hasil penelitian Pusparini (2011) yang dilakukan di beberapa wilayah Sumatera Barat menjelaskan bahwa Di Sumatera Barat daya kreasi masyarakat dalam industri kerajinan yang tinggi sudah terbukti dari zaman nenek moyang dahulu kala. Pembuatan songket Pandai Sikek dari 500 tahun yang dan hasil tenun dari Silungkang bahwa dari tahun 1930 masyarakat merupakan orang-orang yang memiliki jiwa seni yang tinggi, terutama kaum wanita yang memang memiliki keahlian menenun. Dengan semakin 
membaiknya pendidikan di Sumatera Barat tentunya pola pikir kreatif menjadi lebih tinggi. Pada pertenunan modern tingkat inovatifnya mencapai $100 \%$ dan perte nunan tradisional sebesar $68.75 \%$, dimana Silungkang dan Pandai Sikek telah mampu membuat songket menjadi ringan dan nyaman dipakai. Pada bidang usaha sulaman benang emas, di daerah Pariaman tingkat kepercayaan diri para pelaku usaha sedikit rendah (49\%). Sedangkan pada pertenunan tradisional dan modern para pelaku unit usaha memiliki kepercayaan diri yang tinggi $(68.75 \%$ dan $100 \%$ ). Daur hidup (life cycle) indutri bordir/sulaman dan perte nunan pada umumnya memiliki daur hidup (life cycle) yang relatif singkat. Hal ini terlihat pada hampir seluruh Kabupa ten/Kota yang ada di Sumatera Barat, kecuali Kabupaten Sawahlunto dan Tanah Datar (sebesar 25\%) yang melakukan usaha dalam bidang pertenunan. Contoh nya tenun songket, songket digunakan oleh masyarakat pada acara adat dan untuk acara-acara resmi lainnya.

Salah satu wilayah di Sumatera Barat, tepatnya di Nagari Halaban Kecamatan Lareh Sago Halaban, Kabupaten Lima Puluh Kota dianggap sebagai nagari penghasil tenunan tradisi onal/songket. Nagari yang berada di kawasan perbatasan Kabupaten Lima Puluh Kota dengan Kabupaten Tanah Datar itu terletak pada ketinggian 400 hingga 1.000 meter dari permukaan laut, sekitar $28 \mathrm{~km}$ dari ibu kota kabupaten. Data terakhir menunjukkan, nagari ini dihuni oleh 4.956 jiwa yang terhimpun dalam 1.289 kepala keluarga. Umumnya, atau sekitar $25,7 \%$ penduduknya berprofesi sebagai petani atau peternak, sekitar $9,6 \%$ pengrajin, 2,3\% di bidang pertukangan, $1 \%$ pedagang, masingmasingnya $0,5 \%$ PNS dan pensiunan serta sekitar 0,2\% bidan (http://www.limapuluh kota kab.go.id/ berita-halaban-milikiberbagai-potensi-.html). Khusus di bidang kerajinan, hampir setiap kaum wanitanya menggeluti tenun songket secara tradisi onal. Tak hanya ibu rumah tangga, umumnya remaja puteri di nagari ini juga mengisi waktu luangnya sepulang sekolah dengan bertenun songket

\section{B. Perumusan Masalah}

alah satu dampak positif wanita bekerja adalah dari segi ekonomi - akan memberikan kekuatan terha dap pemilikan sumber-sumber ekono mi, penguasaan ilmu pengetehuan serta norma dan nilai yang berlaku dalam masyarakat setempat. Peranan wanita yang bekerja di usaha industri kecil dan industri rumah tangga, bahwa pekerjaan tersebut sudah lama di lakukan dan merupakan pekerjaan mereka sehari-hari, seperti banyak perempuan yang terjun ke usaha bordir/sulaman dan pertenunan sudah merupakan suatu keterampilan yang harus di miliki oleh para perempuan minang, sehingga untuk menekuni usaha tersebut tidak menyulitkan mereka.

Fenomena tingginya partisipasi tenaga kerja wanita dapat dilihat sebagai aktifitas alternatif dalam pemenuhan kebutuhan ekonomi rumah tangga, disamping pekerjaan di sektor lain yang dilakukan oleh laki-laki. Keadaan ini memperlihatkan bahwa andil wanita cukup besar dalam pemenuhan ekonomi rumah tangga, kendati dalam banyak hal sering disebut sebagai penghasil sampingan rumah tangga (Miko, 1991:13; Leovarintos, 2011).

Penelitian yang mengkaji tentang keterlibatan wanita di sektor publik telah banyak dilakukan, seperti yang telah dilakukan oleh Given dan Chatra (1990) yang menyimpulkan bahwa peranan perempuan sangat penting sebagai pedagang di pasar-pasar lokal yang ada di Sumatra Barat, hasil penelitian yang dilakukan di pasar-pasar tersebut menunjukkan bahwa wanita di samping bekerja di bidang pertanian, banyak dari mereka juga berdagang di pasar - pasar lokal. Hal ini memperlihatkan bahwa curahan waktu wanita untuk bekerja relatif lebih besar dari pada laki - laki. Sedangkan penelitian yang di lakukan oleh Elfina (1987) menunjukkan bahwa peranan wanita pedesaan dalam ekonomi rumah tangga sangat besar dalam menunjang perekonomian keluarganya.

Wanita Minangkabau sebagaimana halnya dengan wanita indonesia lainnya, karena rentetan peristiwa sejarah yang hampir sama juga menerima dampak sejarah sosial yang sama. Sewaktu belum 
dikenal sekolah formal, dimana mata pencaharian hanya terbatas pada usaha pertanian, bertukang dan berdagang, pekerjaan dan lapangan kerja wanita minang yaitu dirumah gadang. Sampaisampai wanita dikatakan sebagai limpa peh, amban puruak, san sumarak rumah nan gadang (Mochtar naim 2006: 14-15).

Dengan adanya pendidikan yang

layak bagi kaum wanita tidak saja membuat wanita Minangkabau sekarang sudah bisa bekerja diluar rumah sampai ke kota-kota. Pada umumnya bagi masyarakat Minangkabau tidak jadi masalah jika pendidikan wanita hanya menengah ke bawah dan juga tidak masalah jika pendidikannya hanya madrasah, karena pendidikan madrasah apalagi yang memiliki asrama fungsinya malah untuk tempat pameraman, penanti pinang masak. Nilai seorang gadis yang disekolahkan di madrasah akan naik nilainya dimata orang kampung karena selama sekolah selain mendapat pelajaran juga pengajaran bukan saja untuk memperhalus budi pekerti tetapi juga memperkenalkan dan dipelajarinya berma cam-macam kerajinan dan keterampilan rumah tangga dari jahit menjahit, memasak, berhias dan lain sebagainya dan semuanya adalah untuk persiapan memasuki jenjang rumah tangga. (Mochtar Naim 2006:24)

Berdasarkan latar belakang di atas, maka perumusan masalah adalah bagaimana keseharian wanita perajin tenun tradisional di nagari Nagari Halaban, Kecamatan Lareh Sago Halaban Kabupaten Lima Puluh Kota dalam meningkatkan ekonomi rumah tangga?

\section{Tinjauan pustaka}

1 da dua teori utama tentang peran wanita dan laki-laki dalam masya Urakat yang berusaha untuk menjelaskan sebab-sebab terpusatnya kegiatan wanita di ranah domestik dan kegiatan laki-laki yang terpusat di luar ranah domestik, yaitu: (1) Teori Nature, yang beranggapan bahwa peran laki-laki dan wanita ditentukan oleh faktor biologis; dan (2). Teori Nurture, yang beranggapan bahwa perbedaan peran antara wanita dan laki-laki tercipta melalui proses belajar dari lingkungan. Adanya pembagian kerja antara wanita dan laki-laki menurut Talcott Parsons dalam Budiman (1986), salah seorang penganut teori Nurture disebab kan oleh proses belajar mengajar dan keadaan lingkungan. Sementara itu teori Nature yang antara lain didukung oleh Sigmund Freud, menyatakan bahwa pembagian kerja menurut jenis kelamin disebabkan oleh perbedaan biologis antara wanita dan laki-laki. Pembagian kerja secara seksual yang membedakan wanita dan laki-laki sudah berlangsung sejak dahulu kala, sehingga orang cenderung menganggapnya sebagai sesuatu yang alamiah. Banyak orang percaya bahwa wanita sudah sewajarnya hidup dalam lingkungan rumah tangga. Tugas wanita adalah tugas yang diberikan oleh alam kepadanya, yaitu melahirkan anak, membesarkan anak, melayani suami dan lain-lain. Sedangkan suami pergi keluar rumah mencari nafkah bagi keluarganya. Tidak perlu dipertanyakan apakah pembagian kerja sepeti itu adil atau tidak.

Dalam masyarakat sering adanya anggapan bahwa, pekerjaan wanita di rumah tangga cenderung dilihat sebagai pekerjaan yang kurang berharga dibansing kan dengan laki-laki yang bisa menghasilkan uang. Harga sosial seseorang cenderung untuk dihubungkan dengan kesanggupan mencari uang. Pekerjaan wanita di rumah tangga sering dianggap tidak mempunyai nilai pasar, tidak mempunyai nilai tukar meskipun pekerjaan itu jelas berguna. Dalam suatu masyarakat dengan kondisi seperti itu, tampaknya bahwa keterlibatan wanita di ranah produktif perlu ditingkatkan, karena kemandiriannya secara ekonomi bisa mempengaruhi atau dapat meningkatkan statusnya baik dalam rumah tangga atau dalam masyarakat. Meskipun demikian, masih ada faktor lain, misalnya pendidikan, nilai-nilai budaya dalam masyarakat yang bersangkutan dan lain-lain yang mempe ngaruhi status wanita.

Meskipun sampai saat ini Indonesia belum menempatkan diri dalam suatu keadaan final dalam hal-hal yang telah dicapai oleh wanita, namun dapat dikatakan bahwa kedudukan dan peran wanita di ranah sosial semakin diakui. Walaupun Tingkat Partisipasi Angkatan 
Kerja (TPAK) wanita di Indonesia lebih rendah dibandingkan laki-laki (karena factor social, budaya dan agama), bila dicermati lebih lanjut ada kecenderungan bahwa TPAK wanita terus meningkat dari tahun ke tahun, sedangkan TPAK laki-laki justru cenderung menurun (Ken Suratiyah dalam Irwan Abdullah, 2003). Semakin meningkatnya TPAK wanita mengandung dua arti yang sangat perlu untuk diperhatikan, yaitu : pertama, kecende rungan itu menunjukkan suatu pernyataan semakin banyak wanita yang bekerja; kedua, menimbulkan pertanyaan: apakah semakin banyak wanita yang bekerja itu menjadi tanda meningkatnya status wanita, apakah mereka bekerja pada pekerjaan yang statusnya lebih tinggi atau justru pekerjaan rendahan saja.

Kedudukan gender dalam suatu kebudayaan tertentu dapat dipelajari dari hubungan antara kedua kelompok kelamin yang berbeda, yaitu laki-laki dan wanita. Rogers mengatakan hubungan antar kedua kelompok ini dapat dimengerti dengan dua pendekatan. Pendekatan tersebut adalah distribusi kekuasaan dan perbedaan perilaku (pandangan ideologi). Pendekatan pertama tidak bisa menjadi alat untuk menganalisa kedudukan dari wanita karena di Minangkabau nilai etika lebih diutamakan. Pendekatan kedua, perbedaan perilaku dan pandangan ideologi, bisa menjabarkan suatu panda ngan individu tehadap nilai, norma, dan tujuannya (Boestami, 1992: 85).

Di Minangkabau, wanita mempu nyai peran berbeda dalam kelompokkelompok tertentu. Dalam rumah tangga, wanita menggunakan harta pusaka untuk penghidupan. Wanita Minangakabau ditun tut untuk bisa menjaga keseimbangan dan hubungan baik dengan seluruh laki-laki dalam kerabatnya. Wanita juga yang melaksanakan segala kegiatan upacaraupacara adat di lingkungan kerabat. Bahkan wanita Minangkabau mempunyai peran seperti laki-laki masa kini dalam keluarganya. Wanita tempat seluruh anggota rumah gadang bermusawarah, yang dengan limpapeh rumah nan gadang.Laki-laki Minangkabau dituntut untuk menjadi seorang yang dibutuhkan oleh rumah tangga, keluarga induk, dan masyarakat. Untuk itu, laki-laki menuntut ilmu agama di surau dan mencari nafkah. Dia mempunyai tanggung jawab untuk membimbing kemenakannya.

Penjabaran diatas dapat disimpul kan bahwa tugas wanita dan laki-laki mempunyai orientasi yang berbeda. Orientasi tugas wanita adalah memperta hankan siklus budaya Minangkabau sedangkan laki-laki menjalankan siklus tersebut sesuai dengan perannya. Oleh sebab itu, peran wanita penting dalam kehidupan masyarakat Minangkabau.

Dalam masyarakat khususnya masyarakat Minangkabau pada zaman modern ini kecenderungan pembagian kerja yang cukup jelas berdasarkan jenis kelamin. Dalam rumah tangga Minang, seorang isteri terutama berkewajiban mengurus rumah tangganya, walaupun suami sebagai kepala rumah tangga, suami lebih mengutamakan hal-hal yang berada di luar rumah tangga dan jarang sekali menaruh perhatian terhadap masalah sehari-hari dalam rumah tangga nya. Suami memberikan uang belanjanya pada waktu-waktu tertentu kepada isteri, sedangkan isteri harus mengelola uang itu sedemikian rupa sehingga cukup. Namun demikian konsep mengenai status wanita dalam masyarakat Minangkabau nampaknya juga ditentukan oleh kekuasa annya dalam bidang ekonomi. Dalam hal ini, status wanita Minangkabau tergolong tinggi. Wanita bisa memiliki tanah dan mengawasi penggarapnya. Dengan memiliki tanah ia memiliki kesempatan yang lebih besar untuk menguasai sumbersumber ekonomi strategis dalam masyarakat tersebut. Selain itu, wanita memiliki akses ke sebagian besar pekerjaan termasuk berbagai corak kerja seperti kerja sawah ladang, dagang kecil, jual beli borongan, usaha kecil membantu rumah tangga dan mengajar.

Tentu saja ada beberapa pekerjaan yang tertutup bagi wanita, khususnya yang menuntut kekuatan fisik yang besar. Ketentuan mengenai pemba gian kerja berdasarkan jenis kelamin pada masyarakat Minangkabau, khususnya dalam keluarga, sedikit banyak tergantung pada tipe masyarakatnya. Secara umum ada lima pola kerja sama antara isteri dan suami di dalam rumah tangga keluarga Minangkabau, yaitu: (1). Pola yang lazim di 
perkotaan : suami bekerja di luar rumah, isteri di rumah, kadang-kadang menggarap pekerjaan rumah tangganya sendiri, kadang-kadang mengawasi pembantu yang melakukan segala pekerjaan rumah tangga. (2). Pola yang berlaku pada keluarga petani: suami dan isteri bekerja bersama-sama. Disini tidak terdapaat garis pemisah yang tajam antara dunia laki-laki dan wanita, walaupun pada umumnya terdapat pembagian tugas secara tradisional, misalnya laki-laki membajak sawah dan wanita menyiangi. (3). Suami melakukan pekerjaan produktif utama, isteri melakukan pekerjaan ringan di rumah seperti menjahit, beternak ayam atau berjualan sembako untuk keluarga. (4). Suami dan isteri melakukan dua pekerjaan yang berbeda, kemudian pendapatannya dijadikan satu. (5). Mitra usaha: baik suami atau isteri bekerja bersama. Bentuk yang paling umum dari pola pekerjaan ini ditentukan di kalangan perajin tenun tradisional. Uraian di atas memperlihatkan bahwa konsepsi Minangkabau mengenai kedudukan dan peran wanita dalam masyarakat relatif lentur dan kontekstual, tergantung pada kebudayaan yang berlaku di dalam golongan-golongan masyarakat tertentu (atas, menengah, bawah) maupun tipe-tipe masyarakat tertentu (perkotaan dan pedesaan). Selain itu wanita pun memiliki akses untuk meningkatkan kedudukan sosialnya, antara lain melalui peningkatan perekonomiannya. Keadaan ini dapat saja ditafsirkan sebagai suatu lahan yang baik guna menyemaikan program peningkatan wanita.

\section{Tujuan Dan Manfaat Penelitian}

ujuan yang telah dicapai dalam
penelitian ini adalah mendeskripsikan
keseharian wanita di nagari Nagari Halaban, Kecamatan Lareh Sago Halaban Kabupaten Lima Puluh Kota yang bekerja sebagai perajin tenun tradisional.

Hal yang menjadi manfaat dalam temuan dalam penelitian ini adalah kajiankajian Antropologi Wanita, dalam menggambarkan sosok wanita Minangka bau yang bekerja sebagai perajin tenun tradisional, melalui gambaran keluarga, motivasi, keseharian dalam keluarga dalam meningkatkan ekonomi dalam keluarga. Hal yang menjadi temuan penting adalah dapat melihat baseline data mengenai kedudukan ekonomi wanita Minangkabau yang bekerja dalam upaya membantu ekonomi rumah tangga, yang berhubungan dengan adat istiadat di Minangkabau itu sendiri.

\section{E. Metode Penelitian}

okasi penelitian dilaksanakan di Nagari Halaban, Kecamatan Lareh Sago Halaban Kabupaten 50 Kota. Lokasi tersebut merupakan salah satu daerah yang tergolong sukses menja lankan usaha kerajinan tenun tradisional melalui peran para wanita ru mah tangga yang mencapai $9.6 \%$ perajin tenun tradisional dalam upaya peningkatan ekonomi rumah tangga. Dalam penelitian ini menggunakan pendekatan penelitian kualitatif. Penelitian kualitatif memusatkan perhatian pada prinsip-prinsip umum yang mendasari perwujudan satuan-satuan gejala yang ada dalam kehidupan sosial. Dalam penelitian kualitatif yang dianalisis bukan variabel-variabel tetapi yang dianalisis dalam kaitan hubungan dengan prinsip-prinsip umum dari satuan-satuan gejala lainnya dengan menggunakan budaya masyarakat yang diteliti dan dari hasil analisis tersebut dianalisis lagi dengan menggunakan seperangkat teori yang berlaku (Neuman, 2006:149; Rudito, 2008: 78).

Dalam penelitian kualitatif yang menjadi sasaran kajian adalah kehidupan sosial atau masyarakat sebagai satu kesatuan atau sebuah kesatuan yang menyeluruh. Karena itu, penelitian kualitatif juga biasanya dikaitkan dengan pengertian yang sama dengan pendekatan yang dikenal dalam antropologi yang dinamakan pendekatan holistik. Dalam penelitian kualitatif tidak dikenal sampel tetapi penelitian kasus yang ditelitinya secara mendalam dan menyeluruh untuk mempe roleh gambaran mengenai prinsip-prinsip umum atau pola-pola yang berlaku umum berkenaan dengan gejala-gejala yang ada dalam kehidupan sosial (Rudito, 2008:79).

Penelitian ini berbentuk studi kasus yang mengutamakan penelitian yang menyelidiki fenomena dan konteksnya saling terkait dan memanfaatkan banyak bukti atau informasi untuk mencari data. 
Dalam penelitian studi kasus, keutuhan dari objek perlu dipertahankan. Teknik pengumpulan data yang telah dilakukan adalah menggunakan teknik observasi partisipasi, wawancara bebas dan menda lam dan studi kepustakaan. Pemili han informan diambil secara purposive (sengaja), dimana pengambilan informan yang bersifat tidak acak dan juga berdasarkan pertimbangan-pertimbangan tertentu yang dapat memberikan informasi sesuai dengan masalah yang diteliti. Saat penelitian berlangsung, pemilihan informan dibagi ke dalam dua, yaitu informan kunci dan informan biasa. Menurut Bungin bahwa penentuan siapa yang harus menjadi informan kunci melalui beberapa pertimbangan di antaranya: orang yang bersangkutan memiliki pengalaman pribadi sesuai dengan permasalahan yang diteliti, usia orang yang bersangkutan telah dewasa, orang yang bersangkutan sehat jasmani dan rohani, bersifat netral dan memiliki pengetahuan yang luas mengenai permasalahan yang diteliti (Bungin, 2004:56).

Informan kunci yang telah dipilih adalah 5 wanita yang menggeluti aktivitas tenun tradisional dalam keluarga mereka. Sedangkan informan biasa adalah pejabat pemerintahan nagari dan tokoh-tokoh masyarakat. Berikut ini daftar informan yang berhasil diwawancarai.

Tabel Daftar Informan yang Berhasil Diwawancarai Dalam Penelitian

\begin{tabular}{|l|l|l|l|}
\hline No. & Nama Informan & Umur & Pekerjaan \\
\hline 1 & Fachrurazi, S.H & 45 Tahun & Wali Nagari \\
\hline 2 & Bu In & 40 Tahun & Menenun \\
\hline 3 & Bu Neli & 33 Tahun & Menenun \\
\hline 4 & Bu Chandra & 35 Tahun & Menenun \\
\hline 5 & Bu Ernita & 39 Tahun & Menenun \\
\hline 6 & Bu Irawati & 46 Tahun & Pengusaha Tenun \\
\hline
\end{tabular}

Sumber: Data Primer Penelitian, 2016.

Data-data yang telah dikumpulkan oleh peneliti termasuk juga catatan lapangan dikelompokkan oleh peneliti atas dasar aktivitas khusus yang ada dan diteliti. Kemudian dari pengelompokkan data tersebut, data-data itu kemudian diabstraksikan dan dikaitkan satu dengan lainnya sebagai satu kesatuan kejadian dan fakta yang terintegrasi. Dari abstraksi tersebut maka akan tampak pranata sosial yang berlaku di wilayah atau komuniti tersebut (Bungin, 2004:60).

Dalam menganalisis tentunya selalu terkait dengan konsep yang telah dipelajari sebelumnya. Sehingga dari hasil analisis akan tampak kesesuaian dari data yang diperolehnya dengan konsep yang dipelajarinya atau akan berbeda dengan konsep yang dipelajarinya karena masalah sosial akan selalu berbeda antara satu masyarakat dengan masyarakat lainnya.

Setelah itu disusun sesuai dengan kategori-kategori dan kemudian disimpul kan. Apabila dalam kesimpulan masih menimbulkan keraguan maka dilakukan pengkategorian ulang hingga seluruh data yang telah berhasil dikumpulkan dianggap sesuai dengan tujuan penelitian. Temuan di lapangan akan diolah dengan data yang didapat dari literatur dan akan disajikan dalam suatu karya etnografi deskriptif.

\section{F. HASIL DAN LUARAN YANG DICAPAI}

1. Gambaran Umum Lokasi Pene litian: Kondisi Geografis

$\mathrm{N}$ agari Halaban termasuk dalam wilayah Kecamatan Lareh Sago Halaban, sekaligus merupakan Nagari yang berada di perbatasan Kabupaten Lima Puluh Kota dengan Kabupaten Tanah Datar. Wilayahnya terle tak pada $6^{\circ}$ - $11^{\circ}$ Lintang Utara serta berada pada keinggian $400 \mathrm{~s} / \mathrm{d} 1000$ meter dari permukaan laut. Jarak dari ibu kota Kecamatan $7 \mathrm{Km}$, dari lbu kota Kabupaten Lima Puluh Kota adalah $28 \mathrm{Km}$, sedangkan dari lbu Kota Propinsi Sumatera Barat Ik $140 \mathrm{Km}$. Luas Nagari Halaban Ik. $63 \mathrm{Km} 2$, dengan batas - batas sebagai berikut : 
Sebelah Timur: Berbatas dengan Nagari Ampalu / Kab. Sijunjung

Sebelah Barat: Berbatas dengan Gunung Sago

Sebelah Selatan: Berbatas dengan Kab. Tanah Datar

Sebelah Barat: Berbatas dengan Nagari Tanjung Gadang

Bentuk permukaan Nagari

Halaban merupakan daerah perbukitan dan dataran yang bervariasi tingkat kemiringannya. Secara umum kemiringan wilayah Nagari Halaban dibagi atas kemiringan $8-15 \%$, kemiringan $15-30 \%$, kemiringan $30-45 \%$ dan kemiringan $>45 \%$. Dengan ketinggian 617 diatas permukaan laut. Daerah ini mempunyai type A (Achmidt Ferguson), dengan curah hujan $3870 \mathrm{~mm} /$ tahun. Jumlah bulan basah 10 buan/tahun dengan 2 bulan kering pertahun. Daerah ini mempunyai awal musim hujan pada bulan Agustus. Keadaan iklim pada Nagari Halaban beriklim tropis, dimana suhu udara pada kawasan ini berkisar antara $32^{\circ} \mathrm{C}$ dengan curah hujan 14,93 mm/hari.

\section{Sejarah dan Asal Usul Pembentukan Nagari}

$\mathrm{H}$ asil penelitian berupa sejarah asalusul nagari berdasarkan hasil wawancara dengan Wali Nagari Halaban. Menurutnya, pada permulaaan abad ke 7, nenek moyang meninggalkan Nagari Limo Kaum di Daerah Pariangan Padang Panjang. Nenek kami tersebut terdiri dari dua rombongan. Rombongan pertama terdiri dari Nenek Ganti Nan Mudo, Nenek Lompong, Nenek Juaro, Nenek Jonang, Nenek Untung, Nenek Mandai (Wanita), dan Nenek Mola (Wanita). Rombongan kedua terdiri dari Dt. Rajo Bosa, Dt. Rajo Nan Panjang, Dt. Paduko Alam, Dt. Rajo Bilang, Dt. Sinaro Nan Bagak, Dt. Rajo Dindo dan Dt. Rajo Mangkuto. Dari Limo kaum rombongan pertama terus ke Tabek sawah tangah (yang masih dalam kenagarian Limo Kaum). Dari sinilah dimulai perjalan panjang oleh Nenek moyang kami tersebut yaitu menuju ke Koto Lalang yang terletak dipinggir timur Nagari Tanjuang Bonai (Kec. Lintau Buo sekarang).

Tidak lama kemudian Nenek moyang kami melanjutkan perjalan mereka ke Kalo Kalo. Dari Kalo Kalo Nenek kami meneruskan perjalan mereka ke Tabek Panjang yaitu suatu tempat masuk Kenagarian Lubuk Jantan melintasi Batang Sinamar dan sampai di Tanjung Lansek serta Pamasian. Kemudian setelah beberapa lama mereka tinggal di Pamasian ini, maka mereka melanjutkan perjalanan mereka kearah utara sambil menelusuri Batang sinamar, setelah sampai pada suatu anak sungai yaitu anak batang sinamar dikaki sebuah bukit (bagian dari bukit barisan) berhentilah mereka untuk melepaskan lelah. Ada yang ingin menyeberang Batang sinamar untuk menuju sebuah bukit (Gunung Sago sekarang), ada yang ingin menelusuri batang sinamar untuk melanjutkan perjalanan dan ada pula yang ingin kembali ketempat asal mereka yaitu daerah Pamasian.

Setelah terjadi musyawarah dan mufakat maka perselisihan ini bisa diatasi, sehingga diambil suatu keputusan yaitu satu rombongan akan memudiki batang sinamar menuju utara dan satu rombongan akan meyebera angi batang sinamar menuju gunung sago dan serombongan lagi kembali ke Pamasian. Namun untuk sementara waktu mereka tetap tinggal bersama dilokasi ini yaitu dilereng bukit dipinggir anak sungai tersebut. Dipinggang bukit ini mereka pertama kali membuat sebuah taratak tempat tinggal, oleh karena tempat ini terletak di ketinggian, maka akhirnya taratak ini dinamakan dengan Taratak Tinggi, jadi Taratak inilah yang mula mula dibuat oleh nenek moyang kami. Berhubung karena tempat ini terletak pada tanah yang ketinggian, sehingga tidak memungkinkan untuk membuat persawahan, maka akhirnya tempat ini ditinggalkan oleh rombongan nenek kami menuju tempat yang telah disepakati dahulu.

Satu rombongan Nenek Ganti Nan Mudo, Nenek Lompong memudiki batang sinamar arah ke utara, satu rombongan Nenek Juaro, Nenek Jobang menyeberangi batang sinamar menuju gunung sago dan rombongan nenek Untung kembali ke Pamasian. Nenek Untung sesampai di Pamasian kemudian bergelar Dt. Sati yang ditunjuk sebagai Pucuk Bulat di Pamasian. Sedangkan sebagian kecil rombongan Nenek Untung melanjutkan perjalan ke arah utara 
sehingga di Halaban bergelar Dt. Ganti Nan Sati. Sedangkan rombongan yang memudiki batang sinamar sesampai di pinggiran Batang sinamar ( saat ini bernama Lubuk Lompek), salah seorang dari rombongan yaitu nenek Lompong menyeberangi Batang sinamar, setelah sampai diseberang Nenek lompong membuat sebuah koto yaitu Lakuak Koto.

Setelah Nenek Lompong menyeberang, maka teman temannya Nenek Juaro dan Nenek Ompang melanjutkan perjalanan mudik batang sinamar, tak lama kemudian mereka melihat sebuah bukit disebelah kiri mereka, lalu mereka berjalan menuju bukit tersebut. Setelah sampai dipuncak bukit tersebut ternyata bukit tersebut merupakan sebuah dataran yang luas, lalu mereka sepakat untuk membuat sebuah koto di tempat ini.sehingga tempat ini diberi nama dengan Lambuk Tuo. Sedangkan Nenek Ganti nan mudo, Nenek Jonang, Nenek Mandai dan Nenek Mola yang akan melanjutkan perjalanan menyeberangi Batang sinamar menuju Gunung sago sesampai disuatu tempat yang datar juga membuat sebuah koto yang diberi nama dengan Atas koto. Setelah beberapa lama kemudian maka nenek nenek kami tersebut berkumpul kembali di Koto Lambuak Tuo, karena disinilah tempat yang mereka anggap baik untuk perkampungan. Lalu mereka membuat rumah, menetap dan berketurunan sampai mereka beranak pinak.

Disamping Nenek kami yang masuk dari arah timur, juga ada Nenek kami yang masuk dari arah barat yaitu Nenek kami yang menelusuri Lereng Gunung Sago. Diantara Nenek kami yang menelusuri lereng gunung sago yaitu Dt. Rajo Bosa, Dt. Rajo Nan Panjnag, Dt. Paduko Alam (Dt. Indo Marajo), Dt. Rajo Bilang, Dt. Sinaro Nan Bagak, Dt. Rajo Dindo dan Dt. Rajo Mangkuto. Rombongan Nenek kami ini berasal dari Limo Kaum Pariangan Padang Panjang. Dari Limo kaum mereka meneruskan perjalanan ke Tabek sawah Tangah dan sesampai di sini mereka menetap untuk sementara waktu, sementara rombongan Dt. Ganti Nan Mudo telah jauh lebih dahulu meninggalkan Tabek Tangah Sawah. Untuk mengejar ketinggalan dari rombongan dari barat ini, maka mereka membuat jalan pintas dengan menelusuri lereng gunung sago, dengan harapan semoga mereka dapat bertemu kembali dengan Nenek nenek yang telah berangkat lebih dahulu. Setelah rombongan ini sampai di Batu Bulat, maka mereka beristirahat sejenak untuk melepaskan lelah, kemudian melanjutkan perjalanan menuju Balai Tangah. Disini rombongan menetap untuk sementara waktu guna mencari perbekalan. Tak lama kemudian rombongan berangkat lagi menuju Tanjung Bonai. Di Tanjung Bonai rombongan menetap pula untuk sebentar. Dari Tanjung Bonai mereka melanjutkan perjalanan menuju utara yaitu ke Pauh Tinggi dan terus ke suatu tempat yang bernama Banio Tarang. Di Banio Torang ini menetap pula untuk sementara waktu Dt. Rajo Nan Panjang ,Dt, Rajo Mangkuto.dan Dt. Rajo Bilang dan Dt. Sinaro Nan Bagak berhenti pula diarah utara Banio Tarang, sedangkan Dt. Rajo Basa dan Dt. Paduko Alam (Dt. Indo Marajo) dan Dt. Rajo Dindo meneruskan perjalanannya kearah utara lagi, sehingga waktu itu masing masing nenek kami telah berusaha untuk mencari penghidupan mereka masing masing dengan membuat sawah dan peladangan.

Beberapa waktu kemudian dari Banio Tarang Dt. Rajo Nan Panjang melihat asap orang berkebun di lereng gunung sago arah utara, melihat asap tersebut, maka timbul niat dari Dt. Rajo Nan Panjang untuk meninjau asap tersebut, maka langsung beliau menelusuri jalan ke arah asap tersebut. Sesampai beliau disana ternyata Dt. Rajo Bosa sedang membuat unggun untuk persawahan dan peladangan sehingga kemudian tempat ini diberi nama dengan Dusun Kabun. Oleh karena rasa persaudaraan antara nenek kami tersebut sangat tinggi maka diantara mereka selalu saling mengunjungi, sehingga jalan antara Banio tarang dengan Kabun menjadi lanyah karena saban hari dan saban waktu mereka lalui, sehingga daerah tersebut dinamakan silanyah.

Setelah Nenek kami yang datang dari arah timur dan yang datang dari arah barat telah mendapatkan penghidupan, maka mereka kembali mengadakan hubungan kekeluargaan. Pertemuan mereka dilaksanakan di Lambuak Tuo sehingga baik Nenek kami yang datang dari Timur maupun yang datang dari barat 
sepakat untuk membuat perkampungan. Sehingga Lambuk Tuo mereka jadikan sebagai pusat perkampungan. Walaupun Lambuk Tuo telah dijadikan sebagai pusat perkampungan, namun mereka tetap mengulangi tempat tempat dimana mula mula mereka tempati.

Dibukit Lambuk Tuo inilah Nenek kami lama sekali untuk menetap, karena disinilah mereka berketurunan (berkem bang biak). Pada saat itulah mereka mencari tempat atau daerah daerah untuk dijadikan sawah atau tanah ulayat. Setiap hari mereka berjalan kesetiap pelosok dengan tidak lupa membawa kapas. Setiap ada tempat yang mereka anggap baik untuk dijadikan sawah atau ladang, maka mereka tinggalkan kapas yang dibawa tersebut sebagai tanda dan bahkan ada diantara mereka menggunakan baju dari kapas. Apabila kapas baju tersebut tersangkut pada salah satu ranting kayu, maka tanah sekitar tempat kapas tersangkut tersebut sudah menjadi hak bagi mereka yang empunya kapas tersebut. Apabila ada diantara mereka yang melewati daerah yang telah ada tanda tersebut, maka berarti daerah tersebut telah dikuasai oleh mereka yang telah dahulu menemukan daerah tersebut, maka dengan demikian maka mereka akan mencari tempat yang lain lagi yang belum ada yang menguasai.

Dek langik basentak naik bumi basentak turun, maka orang bertambah ramai juga , maka dengan niat baik Nenek Ganti Nan Mudo membuat koto di Koto Baru, dan Nenek Juaro membuat koto di Koto Tinggi. Tidak lama setelah itu Nenek Ganti Nan Mudo membuat sebuah lagi koto di Kapalo Koto. Setelah Koto koto ini selesai dibuat, maka sepakatlah mereka untuk membuat sebuah Balai pertemuan yang digunakan untuk tempat bermusya warah, lalu dipilih salah satu tempat yang baik yaitu di Atas laban. Lalu dengan bekerja sama dan semangat gotong royong dibuatlah balai tersebut yang merupakan sebuah tempat yang terdiri dari dinding tanah, atap langit dan dinding tanah, sehingga balai ini dinamakan dengan Balai Tanah.

Pada awal abad ke 14 Raja Adat di Pagaruyung memberikan perintah kepada Raja lbadat supaya disetiap daerah dibentuk Raja Raja kecil. Hal ini bertujuan untuk memudahkankan dan lancarnya sistem pemerintahan, maka dengan dasar tersebut disetiap daerah melaksanakan musyawarah penbentukan Raja raja kecil di masing masing daerah atau nagari, maka dengan adanya perintah tersebut maka Nenek kami melaksanakan musyawarah untuk pembentukan raja raja kecil sebagaimana yang dimaksud oleh Raja adat tersebut. Pertama yang dipikirkan oleh Nenek kami yaitu masalah nama Nagari yang akan didirikan, maka suatu ketika datanglah utusan dari Syehk Bantan yang bernama Pakiah Badang kiang. Beliau adalah teman akrab dari Syehk Bantan. Dahulu ketika di Tabek Panjang Syehk Bantan sudah pernah mengajarkan Bismillahirrohmanirrohim ke pada Nenek kami dan bahkan telah dipasihkan pada saat berada di Pamasian. Pada saat itu didapati oleh Pakiah Badangkiang Nenek Juaro sedang memerah susu sapi. Lantas beliau mengatakan HALAL LABAN. Halal artinya baik/boleh, Laban artinya Susu. Jadi Halal Laban artinya Susu yang baik/halal. Dari sinilah nama Halaban yang semula berasal dari kata Halal Laban, sehingga saat itu ditetapkanlah Halaban sebagai nama dari nagari Halaban.

Setelah selesai menyusun sturuktur adat di Nagari Halaban, maka beberapa waktu kemudian datanglah beberapa orang Datuk dari daerah seberang Batang Sinamar diantaranya Dt. Kondo menemui Dt. Rajo Mudo dan menyapaikan maksud kedatangannya kepada Dt. Rajo Mudo dan Nenek Juaro. Adapun maksud kedatangan beberapa orang datuk dari daerah seberang Sinamar adalah untuk menjemput Raja yang akan dijadikan sebagai Pucuak adat di daerah tersebut. Dan setelah dilaksanakan musyawarah antara Datuk dari daerah seberang Batang Sinamar dengan Datuk datuk yang ada di Nagari Halaban, maka diputuskan bahwa yang akan dijadikan Pucuak adat di daerah seberang Batang Sinamar adalah kaum dari Dt. Paduko Alam (Dt. Indo Marajo). Dengan sangat rela dan senang hati sebagian dari kaum Dt. Paduko Alam (Dt. Indo Marajo) bersama Datuk Datuk yang lain melepas kepergian sebagian dari kaum Dt. Paduko alam (Dt. Indo Marajo). Dan sesampai di daerah seberang Batang Sinamar tersebut 
sesuai dengan kesepakatan awal dari Datuk Datuk tersebut, maka Dt. Paduko Alam dijadikan sebagai Pucuak Adat di daerah seberang Batang Sinamar tersebut.

\section{Kondisi Demografi}

$\mathrm{N}$ agari Halaban dihuni oleh 4.956 jiwa, yang terdiri dari 2.519 laki laki dan 2.437 perempuan. Kesemuanya ini terhimpun dalam 1.289 Kepala Keluarga. Pekerjaan yang digeluti oleh Penduduk Halaban adalah 25,7 \% Petani/Peternak, $1 \%$ Pedagang, 0,9\% PNS, $0,5 \%$ Pegawai Swasta, $0 \%$ TNI/Polri, 2,3 \% Tukang, 0,2 \% Bidan, 0,5 $\%$ Pensiunan, 9,6 \% Pengrajin dan Sisanya adalah Pelajar/Mahasiswa serta Pengangguran.

Pada Nagari Halaban, sarana pendidikan yang tersedia terdiri dari TK (Taman Kanak-Kanak), SD (Sekolah Dasar), dan tingkat SLTP (Sekolah Lanjutan Tingkat Pertama).

Untuk sarana pendidikan pada tingkat nagari, sarana pendidikan yang ada telah tersedia pada setiap jenjang pendidikan. Dapat dilihat pada tabel, sarana pendidikan paling banyak yaitu pada tingkat SD sebanyak lima buah, sedangkan yang paling sedikit yaitu TK. Hal ini menunjukkan sangat minimnya ketersediaan fasilitas TK pada nagari ini. Sarana pendidikan pada jenjang TK dapat dilihat pada tabel di atas, hanya tersedia satu buah TK yang menampung 60 siswa. TK yang ada saat ini juga dapat menampung siswa Playgroup, sehingga kegiatan TK dan Playgroup bersamaan. TK ini berstatus swasta yang dimiliki oleh Yayasan Pengembangan Halaban. Untuk sarana pendidikan pada jenjang SD dapat dilihat pada tabel bahwa dengan adanya lima buah SD pada nagari ini dinilai sudah mencukupi kebutuhan dalam nagari. Namun dapat dilihat pada beberapa sekolah, jumlah siswa dinilai sangat sedikit sekali. Hal ini bisa saja disebabkan lokasi sekolah yang cukup jauh dari pemukiman, dan keinginan dari anak-anak untuk bersekolah dan orang tua untuk mendorong anak-anaknya turut berse kolah. Untuk sarana pendidikan pada jenjang SLTP dapat dilihat pada tabel bahwa adanya dua sekolah yang berbeda, yaitu pendidikan pada sekolah biasa dan sekolah keagamaan. Status kedua sekolah ini pun berbeda, SMP 2 merupakan sekolah negeri, sedangkan MTS adalah sekolah swasta yang dimiliki oleh Yayasan Pengembangan Halaban. SMP 2 terletak di Jorong Alang Laweh yang bearti berada pada perbatasan dengan Nagari Tanjung Gadang. Siswa pada sekolah ini tidak hanya berasal dari Nagari Halaban tapi juga berasal dari nagari lain seperti Nagari Tanjung Gadang dan sekitarnya. Sedang kan MTS Halaban ini terletak di Jorong Atas Laban yang juga berdekatan dengan TK yang juga dimiliki yayasan pengembangan Halaban.

Untuk sarana peribadatan pada kawasan rencana peribadatan berupa 8 unit mesjid, 24 unit mushalla. Masjid dan mushalla yang ada di nagari ini sudah terdapat disetiap jorong sehingga perseba rannya cukup baik dan dapat melayani masyarakat dengan baik.

Sarana kesehatan merupakan salah satu faktor penunjang yang sangat penting dalam menunjang kegiatan aktifitas yang ada. Untuk sarana kesehatan pada kawasan Nagari Halaban ini terdapat sarana kesehatan berupa Puskesmas, Polindes dan Posyandu.

Puskesmas pada Nagari Halaban ini hanya ada satu yang terletak di Jorong Alang Laweh. Sebagai Puskesmas yang melayani untuk Kecamatan Lareh sago Halaban, adanya kegiatan pelayanan kesehatan yang relatif tinggi setiap waktunya. Namun, juga telah dibangun puskesmas baru di Nagari Labuh Gunuang yang juga dapat melayani penduduk kecamatan. Puskesmas ini dibantu oleh dua buah Pustu dan beberapa Poskesri yang

Pembangunan sarana perumahan merupakan upaya untuk memenuhi kebutuhan salah satu kebutuhan manusia, sekaligus untuk meningkatkan suatu lingkungan kehidupan dan pergerakan kegiatan ekonomi dalam rangka mening katkan kesejahteraan masyarakat.

\section{Kondisi Sosial Budaya}

$\mathrm{K}$ eadaaan kultur dan budaya masyarakat di Nagari Halaban pada umumnya memiliki karakteristik yang sama dengan wilayah administrasi lainnya, tatanan kehidupan masyara katnya, masyarakat Nagari Halaban menganut sistem kekerabatan berda sarkan hubungan Matrilineal. Yakni 
hubungan kekerabatan dari pihak Ibu. Masyarakat daerah ini hampir seluruhnya pemeluk agama islam kecuali beberapa pendatang. Masyarakat disini bisa diktakan dengan pemeluk agama yang cukup fanatik yang memegang erat aturan-aturan yang ditetapkan oleh Islam dan mengamalkan dalam kehidupan seharihari. Walaupun adat-istiadat masyara katnya masih kental, masyarakat di kecamatan ini selalu bersikap ramah dan terbuka. Pada kegiatan-kegiatan ini, para anak nagari selalu diberikan bimbingan serta krgiatan yang sifatnya positif agar budaya asli nagari tidak akan terlupakan dan terhapuskan akibat dari budaya luar.

\section{Kondisi Perekonomian Masyara kat}

$\mathrm{P}$ ada umumnya masyarakat Halaban bergerak disektor pertanian/ peterna kan dan kerajinan. Dewasa ini ekonomi masyarakat berangsur membaik. $\mathrm{Hal}$ ini disokong oleh adanya irigasi yang baik serta bantuan - bantuan permodalan dari Pemerintah dan Lembaga Keuangan lainnya. Disektor kerajinan, terutama dikerajinan songket merupakan primadona peoduksi kerajinan di Nagari Halaban. Hal ini tampak dari kegiatan pemuda pemudi Nahgari Halaban disektor ini. Sokongan permodalan dari pemerintah dan Bank Dunia melalui PNPM-MPd pun telah berhasil mendongkrak usaha ekonomi kerajinan ini.

Kegiatan perekonomian di Nagari Halaban ini berupa pasar. Pasar mingguan yang dilakukan pada setiap hari selasa ini menjual segala jenis kebutuhan sehari-hari dan hail bumi lainnya. Pasar ini merupakan pasar tradisional yang para penjual dan pembelinya berasal dari Nagari Halaban sendiri dari Nagari Tanjung Gadang. Karena pasar ini hanya satu kali dalam seminggu, jadi kesempatan ini sangat dimanfaatkan oleh penduduk untuk membeli kebutuhan dan keperluan hidup mereka.

Kegiatan pertanian yang ada di Nagari Halaban ini rata-rata modalnya berasal dari swadaya para pelaku kegiatan ekonomi sektor pertanian itu sendiri. Sedangkan untuk yang sifatnya bantuan, jarang di terima oleh para pelaku kegiatan aspek ekonomi sektor pertanian di Nagari

80 | P a g e
Halaban. Oleh sebab itu para petani terpaksa melangsungkan kegiatan tersebut dengan menggunakan modal sendiri.

Pada sektor perkebunan pada Nagari Halaban yang ada hanya perkebunan rakyat. Sedangkan untuk perkebunan swasta terdapat perkebunan teh yang sudah tidak beroperasi lagi. Jenis produksi perkebunan tersebut tersebut komoditas yang di hasilkan kelapa, gambir, kakao dan karet. Daerah pemasaran untuk hasil perkebunan di Nagari Halaban di pasarkan melalui pedagang pengumpul kemudian di salurkan ke pasar Alang Laweh, pasar Payakumbuh dan untuk Gambir di Pasarkan sampai ke India dan Singapura.

Untuk sektor peternakan, jenis produksi ternak yang terdapat pada Nagari Halaban berupa ternak besar dan ternak kecil. Untuk ternak besar yaitu peternakan sapi sedangkan untuk ternak kecil yaitu peternakan ayam potong. Pada sektor industri, yang terdapat pada Nagari Halaban berupa industri penambangan mineral calcium dan beberapa industri rumah tangga berupa industri pembuatan Songket. Pada tabel berikut ini akan dijelaskan mengenai jenis kegiatan industri batu kalsium dan industri songket yang ada di Nagari Halaban.

Industri Songket pada Nagari Halaban merupakan jenis industri rumah tangga yang dilakukan oleh wanita di nagari ini. Kegiatan industri Songket yang ada di Nagari Halaban ini rata-rata modalnya berasal dari modal sendiri. Sedangkan untuk yang sifatnya bantuan, disalurkan melalui kelompok tenun. Bahan baku Pembuatan Songket di dapatkan dari Kota Bukittinggi, bahan yang di butuhkan antara lain: Suri, Karok, Turak, Palapoh, Lidi, Benang, antara lain makau dan suto. Dalam pembuatan satu paket kain Songket di Nagari Halaban di butuhkan waktu selama 15 hari. Alat-alat yang di butuhkan untuk membuat songket di datangkan dari Bukittinggi, dengan harga Rp.1.120.000 per paketnya sedangkan untuk benang seharga Rp.300.000 untuk 2 pak makao dan Rp.24.000 untuk kain suto. Harga jual songket yaitu Rp.950.000 per helai. Songket di Nagari Halaban di pasarkan ke Kota Bukittinggi, melalui pedagang pengumpul yang berupa kelompok Songket. Selain itu, pemasaran Songket 
juga di lakukan dengan cara pengrajin mengantarkan sendiri ke Toko-toko yang ada di Kota Bukittinggi.

\section{Deskripsi Umum Tentang Keraji- nan Tenun Songket Halaban}

a. Kondisi Umum Masyarakat Perajin Tenun Songket Halaban

$\mathrm{M}$ asyarakat perajin tenun songket di nagari Halaban, merupakan perajin tradisional, yang mempero leh kemahiran menenun sebagai warisan ilmu pengetahuan yang diajarkan sejak usia dini bagi kaum perempuan. Sejak usia 7 tahun sampai menjelang dewasa (17 tahun), setiap wanita di nagari Halaban diwajibkan mengenal dan mempelajari cara menenun, baik dengan alat tenun sederhana (gedokan) dan ATBM (Alat Tenun Bukan Mesin) yang berkapasitas besar.

Sebaran perajin tenun songket di 8 Jorong (Aia Baba, Alang Laweh, Padang Tangah, Lompek, Lambuk, Kabun, Atas Laban,dan Kapalo Koto) dikoordinasikan dalam bentuk serikat perajin dengan nama ITH (Ikatan Tenun Halaban), yang berdomisili di kantor wali nagari Halaban. Komunitas IKM tenun Halaban ini berjumlah sekitar 400 orang, dengan 11 (sebelas) koordinator pemasaran atau pengumpul tenunan. Beberapa koordinator telah memiliki sistem manajemen sendiri, sehingga terdapat variasi usaha yang memiliki konsumen tersendiri.

Salah satu koordinator yang dinilai paling maju adalah Evi Songket yang menamakan diri IKM Central Tenun Songket Halaban. Kelompok perajin songket dalam koordinasinya lebih mengembangkan diri kearah desain songket kontemporer melalui pengem bangan variasi ornamen dan penggunaan kombinasi benang sutera, katun dan rayon. Beberapa produk fashion seperti busana muslim, busana pesta, busana adat, kemeja batik-songket, rok panjang, blus, kerudung, selendang dan blazer, telah dicoba dikembangkan secara mandiri.

Ikatan Tenun Halaban (ITH) yang dipimpin oleh Ibu Erlinda, mengkoordinasi seluruh perajin tenun se nagari Halaban. Sebagian besar merupakan penenun songket tradisional yang lebih banyak mengembangkan tema songket tradisi yang sarat dengan filosofi tambo adat Minangkabau. Ragam hias khas Sumatera Barat kemungkinan berasal dari Halaban, karena perajin tenun tradisional rata-rata mengenal hampir sejumlah 90 corak dasar songket beserta makna simbolisnya.

\section{b. Ciri Khas Ornamen Hias Songket Halaban}

$\mathrm{P}$ roduk kerajinan tenun terutama songket tradisional pada umumya berbasis budaya lokal, baik untuk tujuan fungsional adat tradisi maupun untuk tujuan komersial. Tenun khas Halaban memiliki perbedaan dengan tenunan dari daerah lain, yaitu susunan ornamen cenderung ke arah pakan sehingga menghasilkan permukaan kain lebih halus di kedua permukaan dengan image ornamen yang tergambar jelas dan identik. Produk tenun Halaban, sering diungkapkan sebagai tenunan yang berasal dari hati.

Beberapa perajin tenun Halaban yang mencoba mengembangkan desain dengan mengubah komposisi yang keluar dari pakem tradisi, masih bersepakat untuk tetap mengambil intisari filosofi simbolik pada fragmen ragam hias yang merupakan nilai-nilai masyarakat (social values) sebagai bagian pusat perhatian (point of interest) dari keseluruhan tenunan. Wawasan budaya yang melekat di seluruh komponen perajin songket di Halaban, memperlihatkan daya konservasi budaya yang sangat tinggi, sehingga kecerdasan lokal (local intellegence), kearifan lokal (local wisdom), kejeniusan lokal (local genius) serta keaslian atau kekhasan (local genue) dari makna simbolik ragam hias adat, tidak akan mudah pudar.

\section{c. Peralatan Kerja Tenun Songket Halaban}

$\mathrm{M}$ asyarakat tenun songket Halaban telah terbiasa menggunakan alat kerja tenun tradisional yang disebut gedogan, yaitu alat tenun yang dipakai dengan posisi perajin duduk di lantai. Kapasitas produksi tenun songket dengan menggunakan gedogan membutuhkan waktu yang relatif panjang. Alat tenun ini dipergunakan masyarakat karena sifatnya yang praktis, tidak membutuhkan ruangan yang besar, sehingga perajin pada umumnya meman faatkan kondisi alat untuk dapat bekerja di 
rumah di saat waktu senggang. Masyarakat perajin tenun songket Halaban, telah memperoleh sumbangan dari Pemerintah berupa 13 unit ATBM (Alat Tenun Bukan Mesin), namun sejak diterimanya alat sampai saat ini belum pernah dapat difungsikan dengan baik.

\section{d. Profil Wanita Pengrajin Tenun Tradisional dan Aktivitasnya}

\section{Informan 1: Ibu Neli}

$\mathrm{M}$ enurut lbu Neli (33 tahun), yang merupakan penduduk asli Jorong Lompek,

Desa Halaban, Kabupaten Lareh Sago Halaban, tenun tradisional sudah ada di nagari ini semenjak dahulu, sepengetahuan beliau pada saat ia masih kanak-kanak sudah ada masyarakat yang menenun. Ibu Neli pun memulai menjadi pengrajin kain tenun sudah semenjak ia tamat SMP, ia melalukannya karena hobi dan juga karena tuntutan ekonomi di keluarganya ia pun memilih berhenti sekolah dan melanjutkan untuk membantu ekonomi keluarga dengan menenun. Pada saat ini di desa halaban khususnya sudah banyak ibu-bu yang menekuni pekerjaan memenun.

Biasanya ibu-ibu disini melakukan pekerjaan menenun tersebut merupakan pekerjaan sambilan, ini maksudnya adalah dilakukan setelah melakukan rutinitas pokok seperti, mengurus keluarga, anak, suami, ternak, kebun dan ladang, sawah dan lain-lain. Selain dari kalangan ibu rumah tangga ada juga masyarakat dari kalangan remaja dan gadis yang melakukan menenun.

Dalam pengerjaan menenun ibu Neli berperan sebagai pekerja saja untuk penyediaan bahan dan peralatan tenun disediakan oleh distributor yang juga masih warga desa halaban yaitu Usaha Tenun Remanta yang di kelola oleh ibu Irawati. Ibu Neli bisa mengerjakan satu helai kain dalam kurun waktu lima sampai tujuh hari, apabila ada orderan yang memakai target maka ia mengerjakan bisa sampai empat hari sesuai dengan target.

Adapun upah yang di terima ibu Neli setiap satu halai kain adalah sebesar Rp.450.000,00 upah tersebut bahkan bisa lebih tergantung tingkat kerumitan motif yang di minta, apabila rumit bisa mencapai Rp.500.000,00 upah tersebut langsung ia terima pada waktu pengembalian hasil tenunannya. Ada juga kadang-kadang upah sedikit macet ia peroleh, itu pun karena kesalahan penenun sendiri misalnya ada kesalahan dalam motif, dan kecacatan kain hasil tenunan, hanya saja menunggu kain tersebut laku terjual oleh distributor baru bisa mendapatkan upahnya. Penghasilan yang di peroleh tersebut sangat membantu peekonomian keluarganya. Dalam satu bulan ibu Neli bisa menyelesaikan tenun sebanyak tiga sampai lima helai kain. Selain dari menenun kain ibu Neli juga menekuni usaha kecil-kecilan yaitu berdagang gorengan setiap sore dari pukul 14.00 wib smpai pukul 18.00 wib. jadi setiap harinya ibu Neli mulai menenun dari pukul 8.00 wib sampai pukul 13.00 wib. Ibu Neli biasanya melakukan kesalahan dalam menenun hanya pada panjang kain yang kurang biasanya kalau seperti ini di kurangi pula lah upah yang di terima di kurangi.

Waktu yang dibutuhkan dari awal pemasangan benang (mauleh) sampai siap digunakan untuk menenun kira-kira dibutuhkan waktu selama 2 hari setelah itu baru peralatan siap di gunakan untuk menenun. Untuk jenis dan motif tenunan ini ibu neli dan ibu-ibu lainnya jarang yang hafal nama-nama motif tersebut, biasanya mereka hanya mengerjakannya saja sedangkan memsang motif adalah orang dari distributor penyedia bahan.

Dalam pengerjaan menenun ibu neli biasanya dibantu oleh adik kandungnya itupun apabila terlalu sibuk dan banyak pekerjaan yang di lakukan seperti mengerjakan sawah, mengurus anak, ada kegiatan dadakan. Jika hal ini terjadi ibu neli meminta bantuan sudra perempuannya untuk menenun dan untuk hasi upah pun ia bagi rata. Selama melakukan akititas ini ibu neli tidak ada merasa terpaksa karena pekerjaannya santai dan juga melampiaskan hoby beliau.

\section{Informan 2: Ibu Ernita}

Informan lainnya, yaitu ibu Ernita (39 tahun), juga seorang pengrajin tenun di Halaban ia juga salah satu anggota ibu Irawati pemilik usaha tenun Remanta di Halaban. Ibu Ernita bisa menenun sejak ia masih remaja ia belajar di tempat kursus menenun di Desa Halaban. ibu Ernita 
mempunyai alat tenun maka distributor hanya menyediakan bahan, jenis tenuna nnya pun berbeda dengan informan sebelumnya ia mengerjakan tenun dengan tekhnik cukia pengerjaan dengan teknik ini cukup rumit dan membutukhan ketelitian sedikit ekstra maka upah yang ibu Ernita terima pun lebih banyak dari ibu neli, ada sekitar Rp.700.000,00 sampai Rp.1.000. 000,00 perhelainya.

Waktu pengerjaannya juga lebih lama di bandingkan menenun dengan tekhnik lainnya yaitu sekitar sebulan ibu Ernita bisa mengerjakan satu helai kain. Dalam pengerjaan ini ibu Ernita melakukannya sendirian dan ia juga melakukan sambilan disamping pekerjaan pokok yang harus di lakukan yaitu, mengurus rumah tangga, mengurus ternak, keladang dan sawah. Sama halnya dengan ibu Neli pekerjaan ini bisa menjadi pekerjaan sambilan, dan tidak meng ganggu aktifitas rutinan yaitu mengurus rumah tangga. Pekerjaan ini juga sangat membantu meningkatkat perekonomian di keluarganya.

Menurutnya, tenun tradisional sudah ada di nagari ini semenjak dahulu, sepengetahuan beliau pada saat ia masih kanak-kanak sudah ada masyarakat yang menenun. la pun memulai menjadi pengrajin kain tenun sudah semenjak ia tamat SD, ia melalukannya karena hobi dan juga karena tuntutan ekonomi di keluarganya ia pun memilih berhenti sekolah dan melanjutkan untuk membantu ekonomi keluarga dengan menenun. Pada saat ini di desa halaban khususnya sudah banyak ibu-bu yang menekuni pekerjaan memenun. Biasanya ibu-ibu disini melakukan pekerjaan menenun tersebut merupakan pekerjaan sambilan, ini maksudnya adalah dilakukan setelah melakukan rutinitas pokok seperti, mengurus keluarga, anak, suami, ternak, kebun dan ladang, sawah dan lain-lain. Selain dari kalangan ibu rumah tangga ada juga masyarakat dari kalangan remaja dan gadis yang melakukan menenun.

Dalam pengerjaan menenun, informan berperan sebagai pekerja saja untuk penyediaan bahan dan peralatan tenun disediakan oleh distributor yang juga masih warga desa halaban yaitu Usaha Tenun Remanta yang di kelola oleh ibu Irawati. la bisa mengerjakan satu helai kain dalam kurun waktu lima sampai tujuh hari, apabila ada orderan yang memakai target maka ia mengerjakan bisa sampai empat hari sesuai dengan target.

Adapun upah yang di terima informan setiap satu halai kain adalah sebesar Rp.450.000,00 upah tersebut bahkan bisa lebih tergantung tingkat kerumitan motif yang di minta, apabila rumit bisa mencapai Rp.500.000,00 upah tersebut langsung ia terima pada waktu pengembalian hasil tenunannya. Ada juga kadang-kadang upah sedikit macet ia peroleh, itu pun karena kesalahan penenun sendiri misalnya ada kesalahan dalam motif, dan kecacatan kain hasil tenunan, hanya saja menunggu kain tersebut laku terjual oleh distributor baru bisa mendapatkan upahnya. Penghasilan yang di peroleh tersebut sangat membantu peekonomian keluarganya. Dalam satu bulan informan bisa menyelesaikan tenun sebanyak tiga sampai lima helai kain. Selain dari menenun kain informan juga menekuni usaha kecil-kecilan yaitu berdagang gorengan setiap sore dari pukul 14.00 wib smpai pukul 18.00 wib. jadi setiap harinya la mulai menenun dari pukul 8.00 wib sampai pukul 13.00 wib. Ibu Ernita biasanya melakukan kesalahan dalam menenun hanya pada panjang kain yang kurang biasanya kalau seperti ini di kurangi pula lah upah yang di terima di kurangi.

Waktu yang dibutuhkan dari awal pemasangan benang (mauleh) sampai siap digunakan untuk menenun kira-kira dibutuhkan waktu selama 2 hari setelah itu baru peralatan siap di gunakan untuk menenun. Untuk jenis dan motif tenunan ini ibu neli dan ibu-ibu lainnya jarang yang hafal nama-nama motif tersebut, biasanya mereka hanya mengerjakannya saja sedangkan memsang motif adalah orang dari distributor penyedia bahan.

Dalam pengerjaan menenun informan biasanya dibantu oleh adik kandungnya itupun apabila terlalu sibuk dan banyak pekerjaan yang di lakukan seperti mengerjakan sawah, mengurus anak, ada kegiatan dadakan. Jika hal ini terjadi informan meminta bantuan sudra perempuannya untuk menenun dan untuk hasi upah pun ia bagi rata. Selama melakukan akititas ini ibu informan tidak ada merasa terpaksa karena pekerjaannya santai dan juga melampiaskan hoby beliau. 


\section{Informan 3. Ibu Irawati}

Mengenai asal usul keberadaan tenun di nagari Halaban ini menurut ibu Irawati (46 tahun) yang merupakan salah satu pengusaha tenun sekaligus distributor tenun di desa Halaban, beliau juga mempunyai dua ratus orang anggota penenun. masyarakat mulai mengenal kerajinan tenun ini sudah sejak dahulu, kira-kira pada masa penjajahan belanda yang diperkenalkan oleh seorang pengrajin tenun asal Pandaisikek, orang tersebut yang membawa, mengenalkan serta mengajarkan masyarakat Halaban untuk menenun.

Bentuk motif dan corak hasil tenunan dari desa Halaban ini juga sama dengan bentuk motif dan corak dari tenunan Pandaisikek, sampai saat ini masyarakat Halaban yang berperan sebagai penenun masih mempertahankam motif asli Pandaisikek, walaupun ada juga yang mengkombinasikan dengan motif baru sesuai dengan permintaan konsumen. Pada awalnya ibu Irawati memulai belajar menenun sejak tahun 1991, Pada masa itu perekonomian di keluarga ibu Irawati sedang sulit sedangkan ia masih mempunyai tanggungan hidup lainnya yang masih bergantung pada ibu Irawati yaitu tiga orang adiknya yang masih sekolah. pada saat itu ada penenun dari Pandaisikek yang sedang mengadakan pelatihan menenun bagi masyarakat di Halaban, beliaupun tetarik untuk mengikuti pelatihan tersebut, ada sekitar enam bulan ibu Irawati mengikuti pelatihan sampai ia benar-benar bisa menenun.

Awalnya ia hanya menjadi karyawan upahan menenun kain, dengan upah per satu helai kain siap tenun adalah sebesar Rp,45.000. pada waktu itu harga kain tenun satu pasangnya berkisar $\mathrm{Rp}, 150.000,00$. Ada sekitar dua tahun ibu Irawati menjadi karyawan pada usaha tenun salah satu masyarakat, sementara itu mereka juga membuat suatu kelompok penenun di Halaban yang anggota kelompoknya terdiri dari masyarakat, sementara itu secara pribadi ibu Irawati juga mulai belajar hal-hal mengenai pemasaran kain tenun.

Mula-mula ia memodali semua bahan dan peralatan tenun, modal tersebut diperoleh dari dana pinjman bergilir dari

84 | P a g e
Dinas KOPERINDAG kemudian mencoba menenun sendiri di bantu oleh beberapa orang yang masih keluarga ibu Irawati, salah satunya adalah adik kandung ibu irawati sendiri kemudian hasil tenunan tersebut ia memasarkannya ke Bukittinggi. Seiring berjalannya waktu sejak awal ia memulai usaha tenun hingga saat ini ibu Irawati sudah memiliki sekitar 200 orang karyawan pengrajin tenun yang terdiri dari ibu rumah tangga, remaja yang baru tamat sekolah dan aja juga beberapa orang kaum lelaki yang juga hoby mennenunun. dari 200 orang karyawan tesebut ada sekitar 7 orang yang pada saat ini tidak aktif karena mereka sedang hamil, mereka pun bisa kembali bekerja setelah melahirkan biasanya setelah dua bulan pasca melahirkan mereka kembali aktif menenun.

Dalam system penggajiannya ibu irawati menggaji karyawan tergantung kriteria keahlian masing-masing karyawan dalam menenun, kemudian juga melihat dari tingkat ketelitian yaitu halus kasarnya hasil tenun, ada juga sesuai dengan tingkat kerumitan motif tenunan itu sendiri kemudian juga ada beberapa karyawam ibu irawati yang menyediakan bahan benang untuk tenun, kalau seperti ini tergantung ibu irawati karena ia memilih hasil tenun tersebut terkadang ada warna yang tidak cocok, apabila cocok maka kain tenun tersebut diambil dan langsung membayarkan upahnya.

Motif yang paling rumit dan paling mahal biasanya bahan yang digunakan adalah sutera dan uah yang diberika berkisar Rp 3.000.000,-, semua peralatan dan bahan ibu ira yang menyediakan kalau upah tenun yang type standar sebesar $\mathrm{Rp}$ $400.000,00$. Jenis motif kain beragam tapi dalam pengerjaannya ada yang namanya system banang satu, banang dua, sutera, semi sutera, motif semacam, motid macam-macam dan ada yang tabor. Nama motif kain tenun dan produksi ibu irawati adalah saik galamai, pucuak rabung, bungo saga, kaluak paku, piala, anggur, rantai, saluak laka (selo-selo), katupek, kelok sambilan, bungo paga, bintang baragi, kali-kali, dan itiak pulang patang. Biasanya semakin rumit motif waktu yang dibutuhkan dalam proses pembuatan kain tenun juga semakin lama seperti bahan sutera, system cukia, benang satu dan

Wanita Pengrajin Tenun Tradisional 
benang dua waktu yang dibutuhkan kirakira hingga satu bulan, sebaliknya jika motif standar dan bahan beang tenun biasa untuk memerlukan waktu empat sampai tujuh hari saja.

Motivasi ibu Irawati memilih usaha tenun ini adalah ia melihat banyaknya tingkat pengangguran masyarakat disini, ada pula sebagian anak-anak yang putus sekolah, ada yang pergi merantau ke Batam sedangkan di rantau belim tentu memperoleh kerja, ibu-ibu rumah tangga di kampung ini banyak waktu luang setelah mengurus rumah tangga, lading dan ternak, dari situlah ibu irawati termotivasi untuk melakukan pelatihan bagi sasarannya tersebut. Mengajarkan caracara menenun. Hal ini juga terbayangkan dapat membantu meningkatkan ekonomi mereka.

Lagi pula ibu Irawati juga sudah mengetahui mengenai cara pembuatan dengan mengikuti pelatiha-pelatihan dan pemasaran kain tenun karena ia sudah terjun langsung ke pasar tempat penjualan kain tersebut. Dengan itulah timbul semangatnya untuk terus mengem bangkan usahanya. Karena itulan ibu Irawati sering mengikuti berbagai pelatihan-pelatihan mengenai menenun dan pasar pemasaran kain tenun tersebut. la mengikutinya dimanapun diadakan pelatihan yang ia ketahui, baik di dalam provinsi maupun di luar provinsi. Karena yang menghandal usaha ini beliau dan adik perempuannya maka jika ia mengikuti pelatihan-pelatihan tersebut yang mengontrol usahanya tersebut adalah adiknya.

Hal ini semua tidak terlepas dari dukungan keluarga ibu irawati untuk mengembangkan misinya. Lagi pula karena pengertian dan dukungan terse butlah dalam mengurus rumah tangga ibu ira tidak merasa kewalahan atu repot mengurus rumah tangganya.

Omset yang beliau peroleh dari usaha tersebut dalam satu bulannya kirakira $10 \%$ dari jumlah hasil penjualan. Selama menjalankan usaha ini ibu ira juga pernah merasa jenuh, pusing karena system penjualannya titipan jadi terkadang uang belum keluar sedangkan ia harus membayar upah para pekerja. Biasanya seperti ini terjadi pada bulan puasa. Sedangkan permintaan ramai terjadi pada bulan Agustus.
Pelatihan-pelatihan yang diperoleh anggota tenun ibu Irawati langsung dari dinas pemerintahan. Semenjak adanya usaha-usaha seperti ini sangat membantu peningkatan taraf perekonomian masyarakat di desa halaban. Selain dari usaha tenun, ibu Irawati juga memiliki usaha lainnya seperti ladang, sebagai pengepul karet yang dilakoni oleh suami dan adik laki-lakinya, ada juga usaha ayam broiler (pedaging), lading karet dan lading jahe. Untuk ladang tersebut dikerjakan oleh orang lain tetapi masih keluarga juga dengan system pembagian seperduaan.

Ada istilah istilah mengenai tekhnik menenun yaitu, turak satu dan turak dua. Turak satu adalah setiap motif masuk benang satu helai, turak dua adalah setiap motif masuk benang dua, begitu seterusnya. Dilihat dari fisiknya turak satu semakin halus, dan turak dua sampai seterusnya lebih kasar tergantung banyak turak yang dilakukan dalam menenun kain. Jenis-jenis benang untuk bahan tenun adalah benang produk singapur dan sachi produk jepang, harganya pun berbedabeda. Harga benang yang paling tinggi biasanya sampai Rp $300.000,00$ per benang untuk kain satu helai tenun dibutuhkan sekitar dua bungkus. Hasilnya di jual seharga Rp.3.500.000,00 tapi kalau suah di pasarkan di Jakarta harganya berbeda lagi lebih tinggi yaitu hingga Rp5.000.000,00 dan harga kain yang kualitasnya standar harganya $\mathrm{Rp}$ $1.500 .000,00$ di Jakarta berbeda lagi harganya lebih tinggi yaitu kisaran $\mathrm{Rp}$ $1.700 .000,00$ sampai Rp 2.500.000,00.

\section{G. PENUTUP}

ari hasil penelitian pada beberapa informan wanita perajin tenun tradis ional dapat di ketahui bahwa para perempuan di nagari tersebut mempunyai peranan ganda dalam kehidupan seharihari, selain ibu rumah tangga ia juga sebagai pencari nafkah kedua setelah suaminya, secara ekonomis seorang perempuan mempunyai kedu dukan dan peranan penting dalam rumah tangganya. lkut sertanya perempuan sangat di butuhkan untuk mengatasi kesukaran hidup dan kemelaratan yang menimpa keluarganya.

Peranan pekerja perempuan dalam dunia kerja telah memberikan kontribusi yang sangat penting untuk 
pendapatan keluarga. hal tersebut memper lihatkan bahwa kontribusi pendapatan pekerja perempuan dalam keluarga sangat bervariasi, namun pada umumnya penda patan pekerja perempuan rata - rata lebih besar jika di bandingankan dengan pendapatan suami. Hal ini menunjukkan bahwa peranan pekerja perempuan dalam ruang lingkup keluarga sangat menentu kan kelangsungan hidup keluarga terutama menyangkut dengan keuangan keluarga. Jika segenap lapisan masya rakat (pengrajin, anak tenun, pedagang dan pengusaha songket) ikut merasakan manfaat penggunaan teknologi tenun tradisional, yaitu tingkat upah harus lebih tinggi dari tingkat upah petani atau upah pekerja seni ukir/pahat, hal ini akan menyemangati pengrajin sekaligus akan memotivasi orang tua untuk mengajarkan skill bertenun pada putra-putri nya sejak usia tamat sekolah dasar, seperti zaman sebelum era reformasi.
Potensi anak laki-laki dan wanita sama untuk punya skill bertenun. Jika dikaitkan dengan peran gender atau pembagian kerja secara sosial, maka anak perempuan lebih berpotensi, bertenun dikerjakan di rumah sambil menjalankan tugas dalam rumah lainnya. Streotype wanita dianggap lebih memenuhi syarat untuk mempunyai skill bertenun: selain kemauan harus teliti, sabar, tekun,rajin \& punya cita rasa seni dalam hal membuat motif \& kombinasi warna benang. Usaha Tenun didominasi oleh wanita, sebagai anak tenun, pedagang tenun bahkan pengusaha songket, walau mereka bukan pencari nafkah utama dalam keluarga, bahkan masyarakat matriarkat wanita sangat dilindungi secara ekonomi. Kenyataannya karena wanita dominan dalam usaha bertenun, bahkan sebagian mereka adalah menjadi tulang punggung keluarga, secara otomatis penghasilan prioritas digunakan untuk kebutuhan keluarga sehari-hari.

\section{Daftar Pustaka}

Babbie, Earl 1983. The Practice of Social Research. Belmont, California: Wadsworth Publishing Company.

Boestami, 1992, Kedudukan dan Peranan Wanita dalam Kebudayaan Suku Bangsa Minangkabau. Padang: Esa

Budiman, Arief. 1986. Pembagian Kerja Secara Seksual : Sebuah Pembahasan Sosiologis Tentang Peran Wanita di dalam Masyarakat. Jakarta: PT. Gramedia.

Denzim Norman K. and Yvonna S. Lincoln (ed), (1994), Handbook of Qualitative Research, USA: Sage Publications.

Elfina, Mira. 1987. "Peranan Wanita Pedesaan Dalam Membantu Rumah Tangga”. Laporan Skripsi jurusan Sosiologi - Antropologi. Unand Padang

Given Flud Van dan E. Catra. 1990. "Wanita di Pasar Minangkabau", Makalah Seminar PPK. UGM dan PSK Unand Padang.

Irwan, Abdullah,2003. Sangkan Peran Gender, Jakarta : Pustaka Pelajar.

Kementerian Koperasi dan UKM Republik Indonesia, 2010. Data UKM yang dikelola oleh perempuan Indonesia . Jakarta.

Leovarintos, Rino, 2011. "Alokasi Waktu Perempuan Dalam Aktivitas Industri Kacang Rendang (Studi Kasus: Pekerja Perempuan di Nagari Sawah Tangah Kecamatan Pariangan Kabupaten Tanah Datar)". Skripsi yang tidak dipublikasikan

Mansur, A, dkk, 2008. "Key Succes Factor Perempuan Dalam Mengelola Dan mengembangkan UMKM (Study Kasus) Di Kabupaten Sleman Yogyakarta". Prosiding Seminar Nasional Teknoin.

Miko, Alfan. 1991. Pekerja Wanita Dalam Industri Rumah Tangga Sandang di Propinsi Sumatra Barat. Pusat Penelitian Kependudukan UGM. Yokyakarta.

Neuman, W. Lawrence (1997), Social Research Methods: Qualitative and quantitative approaches. London: Allyn and Bacon.

Priminingtyas, D.N, 2010. "Peran Perempuan Dalam Pengembangan Sektor Usaha mikro Kecil Menengah (UMKM)". Makalah yang tidak dipublikasikan 
Pusparini, 2011. Strategi Pengembangan Industri Kreatif Di Sumatera Barat (Studi Kasus Industri Kreatif Subsektor Kerajinan: Industri Bordir/Sulaman Dan Pertenunan). Perencanaan Pembangunan Pascasarjana Universitas Andalas Padang. Tesis yang tidak dipublikasikan.

Setiawati, R. 2001. "Faktor-faktor yang mempengaruhi produktifitas tenaga kerja wanita pada industri kecil di kota Jambi”. Jakarta: Jurnal Pemberdayaan Perempuan; Nimu Laut.

Vredenbregt, (1983), Metode dan Teknik Penelitian Masyarakat, Jakarta: PT. Gramedia.

Internet

Amalia S.G, Linda, 2013, "Tingkatkan Peran Perempuan dalam Sektor UKM". Suara Karya Online, diakses tanggal 1 Agustus 2016, Jam 08.00 Wib.

Faraz, Nahiyah Jaidi, 2013. "Peran Perempuan dalam UMKM", Makalah yang dipublikasikan dalam staff.uny.ac.id/sites/default/files/.../dr.../peran-sertaperempuan-dalam-umkm.pdf, diunduh tanggal 2 Agustus $2016 \mathrm{Jam} 16.00$

http://www.limapuluhkotakab.go.id/berita-halaban-miliki-berbagai-potensi-.html), diakses tanggal 4 Agustus 2016, Jam 10.30 Wib. 